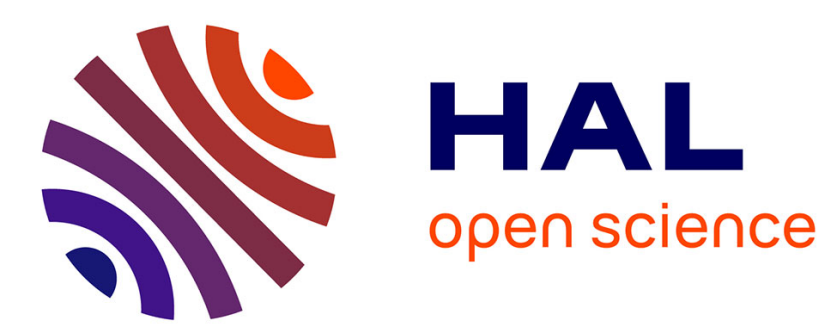

\title{
Variability of quantal NMDA to AMPA current ratio in nucleus tractus solitarii neurons
}

Caroline Strube, Florian Gackière, Layal Saliba, Fabien Tell, Jean-Pierre

Kessler

\section{- To cite this version:}

Caroline Strube, Florian Gackière, Layal Saliba, Fabien Tell, Jean-Pierre Kessler. Variability of quantal NMDA to AMPA current ratio in nucleus tractus solitarii neurons. 2017. hal-03501363

\section{HAL Id: hal-03501363 \\ https://hal.science/hal-03501363}

Preprint submitted on 23 Dec 2021

HAL is a multi-disciplinary open access archive for the deposit and dissemination of scientific research documents, whether they are published or not. The documents may come from teaching and research institutions in France or abroad, or from public or private research centers.
L'archive ouverte pluridisciplinaire HAL, est destinée au dépôt et à la diffusion de documents scientifiques de niveau recherche, publiés ou non, émanant des établissements d'enseignement et de recherche français ou étrangers, des laboratoires publics ou privés. 
1 Title : Variability of quantal NMDA to AMPA current ratio in nucleus tractus solitarii neurons

2

3

4

5 Authors : Caroline Strube ${ }^{1}$, Florian Gackière ${ }^{1 *}$, Layal Saliba $^{1}$, Fabien Tell $^{1}$ and Jean-Pierre Kessler ${ }^{1,2}$

6

7

8 Author's affiliation :

$9 \quad{ }^{1}$ Aix Marseille Université, CNRS, CRN2M UMR 7286, Marseille, France

$10 \quad 2$ Aix Marseille Université, CNRS, IBDM UMR 7288, Marseille, France

11

12

$13 *$ * Present address : Neuroservice, Domaine de Saint Hilaire, 595 rue Pierre Berthier, CS 30531-13593

14 Aix en Provence cedex 03, France

15

16

17 Corresponding author : Jean-pierre Kessler

18 IBDM, UMR 7288 CNRS, Case 907, Parc Scientifique de Luminy, 13009 Marseille.

19 Email : jean-pierre.kessler@univ-amu.fr. 


\section{Abstract}

21 The ratio between AMPA and NMDA receptors is a key factor governing integrative and plastic

22 properties of excitatory glutamatergic synapses. To determine whether the respective proportions of

23 AMPA and NMDA receptors are similar or vary across a neuron's synapse, we analyzed the variability

24 of NMDA and AMPA currents in quantal responses recorded from neurons located in the nucleus

25 tractus solitarii. We found that the average NMDA to AMPA current ratio strongly differed between

26 recorded neurons and that most of the intra-neuronal current ratio variability was attributable to

27 fluctuations in NMDA current. We next performed computer simulations with a Monte Carlo model of

28 a glutamatergic synapse to estimate the part of AMPA and NMDA currents fluctuations induced by

29 stochastic factors. We found that NMDA current variability mainly resulted from strong channel noise

30 with few influence of release variations. On the contrary, partly because of the presence of

31 subconductance states, AMPA receptor channel noise was low and AMPA current fluctuations tightly

32 reflected changes in the amount of glutamate released. We next showed that these two factors, channel

33 noise and fluctuations in glutamate release, were sufficient to explain the observed variability of the

34 NMDA to AMPA current ratio in quantal events recorded from the same neuron. We therefore

35 concluded that the proportion of AMPA and NMDA receptors was similar, or roughly similar, across

36 synapses onto the same target cell. 


\section{INTRODUCTION}

39 Excitatory glutamatergic synapses in the vertebrate central nervous system (CNS) transmit via two

40 types of ligand gated ion channels, the AMPA and the NMDA receptors. These two types of receptors

41 differ by their pharmacological and biophysical properties. AMPA receptors are low affinity ligand-

42 gated channels with fast deactivation whereas NMDA receptors are high affinity receptors with

43 prolonged activation (Traynelis et al., 2010). Consequently, they have different roles. AMPA receptors

44 mainly detect fast glutamate transients whereas NMDA receptors also sense slowly changing and steady

45

46

47

48

49

50

51

52

53

54

55

56

57

58

59

60

61

62 state glutamate levels (Yang and Xu-Friedman, 2015). In addition, being highly permeable to calcium ions, NMDA receptors play a key role in activity-induced long term changes in synaptic strength and neuronal excitability. Because of these differences in role and behavior between the two receptor types, the NMDA to AMPA receptor ratio is a key parameter that strongly influences the integrative properties of excitatory synapses. Expression levels of AMPA and NMDA receptor subunits in post synaptic membranes are highly variable and depend on the region investigated, the target neuron type and/or the origin of the fibers that give rise to the presynaptic boutons (Nusser et al., 1998; Nyiri et al., 2003; Shinohara et al., 2008; Tarusawa et al., 2009; Dong et al., 2010; Fukazawa and Shigemoto 2012; Rubio et al., 2014). Furthermore, several forms of synaptic plasticity rely on changes in postsynaptic receptor numbers, especially AMPA receptors numbers, indicating that receptor expression levels at synapses may vary with time and state (Turrigiano, 2000). The factors that determine the relative abundance of AMPA and NMDA receptors in a particular synapse remain largely unidentified. Several studies suggest that the ratio between the two receptors is for a large part a pathway-specific property. In CA1 pyramidal cells for instance, responses from perforant path and Schaffer collateral synapses differ by their AMPA to NMDA charge ratio (Otmakhova et al., 2002). Likewise, cortico-striatal and thalamo-

striatal pathways elicit responses with different NMDA/AMPA current ratios in striatal neurons (Smeal 61 et al., 2008; Ellender et al., 2013). Thalamic reticular neurons also receives two types of inputs with 2 different NMDA/AMPA current ratios (Deleuze and Huguenard, 2016). However, these data should be 
63 interpreted with caution. As discussed in Myme et al (2003), synaptic responses evoked by electrical

64 stimulation of afferent pathways may fail to provide a reliable view of receptor equipment at synapses.

65 Other studies provide a different view. Recordings performed on hippocampal and neocortical neurons

66 show that the amplitudes of AMPA and NMDA receptor currents are correlated across quantal events

67 recorded from the same cell, suggesting that different synapses onto the same target neuron have a

68 relatively constant ratio of each receptor type (Gompert et al., 1998 ; Umemiya et al., . 1999; Watt et al.,

69 2000; Myme et al., 2003; Watt et al., 2004).

70 The aim of the present study was to determine whether AMPA to NMDA receptor ratio is similar or

71 varies across synapses onto the same neuron. We investigated this question by analyzing the sources of

72 current fluctuations across quantal synaptic responses recorded from a single neuron. Our main

73 objective was to determine whether current ratio variability was high, suggesting heterogeneity of

74 synapses as regards receptor ratio, or low enough to be fully explainable by stochastic factors known to

75 induce current fluctuations at a single synapse (channel noise, variations in vesicular transmitter

76 content). Recording of miniature excitatory post-synaptic currents (mEPSCs) were obtained from

77 retrogradely-identified output neurons of the nucleus tractus solitarii (NTS), a brainstem sensory relay

78 nucleus which receives glutamatergic inputs from visceral afferent fibers via the glossopharyngeal and

79 the vagus nerves and in turn projects onto various brain regions (see Baude et al., 2009 for review). The

80 contribution of stochastic factors to AMPA and NMDA current variability was estimated both by a

81 theoretical approach based on the binomial law and by computer simulations performed using a

82 stochastic synapse model.

\section{METHODS}

84 Experiments were performed on young (3-6 weeks old) male Wistar rats. All procedures were in 85 agreement with the European Communities Council directive (86/609/EEC).

\section{Electrophysiological recordings}

87 Recordings were obtained from NTS projections neurons identified by retrograde tracing (Strube et al.,

88 2015). Briefly, young adult rats were anesthetized by an intraperitoneal injection of a mixture of

89 ketamine (50 mg/kg, Imalgène 1000, Centravet, Lapalisse, France) and xylazine (15 mg/kg, Rompun 
$902 \%$, Centravet) and placed in a stereotaxic apparatus with the incisor bar $2 \mathrm{~mm}$ below horizontal.

91 Tracing was performed using either red RetroBeads (undiluted Rhodamine-labeled latex microspheres,

92 Lumafluor Inc., Naples, FL, USA) or Fluorogold (2\% in 0.2\% saline, Fluorochrome LLC., Denver, CO,

93 USA). Tracer (100 nl) was pressure-delivered through a Hamilton syringe connected to a stainless

94 needle (ID: $0.15 \mathrm{~mm}$, OD: $0.25 \mathrm{~mm}$ ) at a rate of $1 \mathrm{nl} \mathrm{s}-1$ in the parabrachial nucleus (PBN) or the

95 caudal ventrolateral medulla (CVLM). After wound closure and recovery from anaesthesia, the animals

96 were housed individually. Preparation of medullary slices was made as described before (Balland et al.,

97 2006, 2008; Strube et al., 2015) four to seven days after retrograde tracer injection. For recordings,

98 slices were perfused in a chamber at around $3 \mathrm{ml} / \mathrm{min}$ with oxygenated ACSF containing (in $\mathrm{mM}$ ) 120

$99 \mathrm{NaCl}, 3 \mathrm{KCl}, 26 \mathrm{NaHCO}_{3}, 1.25 \mathrm{KH}_{2} \mathrm{PO}_{4}, 0.5$ ascorbate, 2 pyruvate, 3 myoinositol, 10 glucose, 2.5

$100 \mathrm{CaCl}_{2}, 2.5 \mathrm{MgCl}_{2}, 0.02 \mathrm{D}$-serine and a mixture of $\mathrm{GABA}_{\mathrm{A}}$ receptors blockers (in $\mu \mathrm{M}$ : 20 bicuculline,

101100 picrotoxin) at $32^{\circ} \mathrm{C}$. Labeled neurons were visualized using a upright microscope (BX51WI,

102 Olympus Corp., Tokyo, Japan) equipped for fluorescence detection. Whole-cell patch-clamp of NTS

103 neurons were made with an Axopatch 200B (Axon instruments, Foster city, CA, USA), filtered at 2

$104 \mathrm{kHz}$ and digitized at $20 \mathrm{kHz}$. Series resistance was monitored throughout the experiment and neurons in

105 which this parameter was $>20 \mathrm{M} \Omega$ or not stable were discarded. Patch electrodes (2-4 M $\Omega$ ) contained

106 in mM: 120 cesium methane sulfonate, $10 \mathrm{NaCl}_{1} 1 \mathrm{MgCl}_{2}, 1 \mathrm{CaCl}_{2}, 10$ EGTA, 2 ATP, 0.3 GTP, 10

107 Glucose, 10 HEPES ( $\mathrm{pH}$ 7.4). Recordings were performed at $+40 \mathrm{mV}$ in order to remove NMDA

108 receptor magnesium block. To record mEPSCs, $1 \mu \mathrm{M}$ TTX was added to the external solution. A

109 computer interfaced to a 12-bit A/D converter (Digidata 1200 using Clampex 9.x; Molecular Devices

110 LLC, Sunnyvale, CA, USA) controlled the voltage clamp protocols and data acquisition.

\section{Data analysis}

112 Detection of mEPSCs was carried out using the event detection module from the Clampfit software

113 (pClamp, Molecular Device). To prevent any loss of data, detection was performed with two templates,

114 corresponding to events with high or low NMDA/AMPA current ratio respectively, using a loose

115 template match stringency (threshold set to 4). False positives were removed by visual examination of

116 each putative event. A minimum of $30 \mathrm{mEPSCs}$ were collected per neuron. AMPA current amplitude

117 ( $\left.\mathrm{I}_{\mathrm{AMPA}}\right)$ was measured at the peak of the mEPSC (current averaged over $0.3 \mathrm{~ms}$ ). NMDA current 
118 amplitude $\left(\mathrm{I}_{\mathrm{NMDA}}\right)$ was obtained by averaging current within a time window starting $5 \mathrm{~ms}$ after onset.

119 We used 5ms duration time windows (as in Watt et al 2000, Hanse and Gustafsson 2001, Myme et al.

$1202003)$ since long averaging periods $(50 \mathrm{~ms})$ resulted in very high dispersion of data. Measures of

121 variability for $\mathrm{I}_{\mathrm{AMPA}}, \mathrm{I}_{\mathrm{NMDA}}$ and $\mathrm{I}_{\mathrm{NMDA}} / \mathrm{I}_{\mathrm{NMDA}}$ ratio were obtained by calculating variances $(\sigma)$ and/or

122 coefficients of variation (CVs). CVs were used when dimensionless comparison was required.

123 Statistical analysis were performed using the Graphpad Instat software.

\section{Computer simulation}

125 Simulation was performed using a Monte-Carlo model of a glutamatergic synapse (Kessler, 2013). The 126 radii of the axon-dendrite apposition and of the active zone-PSD interface were $500 \mathrm{~nm}$ and $200 \mathrm{~nm}$, 127 respectively. No glial membrane or glutamate transporter was included in the model. Glutamate was 128 released in front of PSD center. Depending on the experiment, the number of glutamate molecules 129 released at each synaptic event was either set to 3000 or made variable around a 3000 average value 130 using a Gaussian random number generator. Quantum size was limited by low and high cut-offs set at 1311000 and 9000 molecules respectively. Glutamate diffusion was calculated using the equation for

132 Brownian displacement in a three dimensional space:

$133<r^{2}>=6 D t$

134 The elementary time step $\mathrm{t}$ was set to $10 \mathrm{~ns}$ and the coefficient of diffusion for glutamate $\mathrm{D}$ was set to $1350.4 \mu \mathrm{m}^{2} . \mathrm{ms}^{-1}$. AMPA and NMDA receptors were randomly placed in the PSD. NMDA receptors were a 136 mix of GluN2A- and GluN2B-containing receptors (2:8 ratio) to comply with the known presence of 137 GluN2B subunits in NTS NMDA receptors (Zhao et al., 2015). AMPA receptor activation was

138 calculated using the kinetic scheme and rate constants for GluA2-containing receptors from Robert et 139 al. (2005). NMDA receptor activation was calculated using the kinetic scheme 4 from Erreger et al. 140 (2005) and temperature-adjusted rate constants from Santucci and Raghavachari (2008). Temperature 141 correction of NMDA receptor rates was necessary to get rise and decay phases matching those obtained 142 in recording experiments in order to perform measurements in similar conditions. Binding probabilities $143\left(P_{o n}\right)$ were calculated from association rate constants $\left(k_{o n}\right)$ using the following formula: 
$P_{o n}=\frac{k_{o n} d t}{0.5 N_{A} A_{T} \sqrt{2 D d t}}$

145 where $N_{A}$ is the Avogadro number, $A_{T}$ is the receptor surface area set to $100 \mathrm{~nm}^{2}$ and $D$ is the diffusion

146 coefficient for glutamate in water (see Kessler 3013, for details). The receptor surface area $A_{T}$ was used

147 to calculate both collisions of glutamate molecules with receptors and binding probabilities. Thus, it

148 exact value had no incidence on the output of the simulation provided that it was set below an upper

149 limit given by the inverse of the receptor density. The accuracy of binding probability calculation was

150 verified by comparing association curves (without dissociation) obtained by Monte-Carlo methods with

151 those obtained by solving ordinary differential equations using a very simple model consisting in a

152 finite disk (500 $\mathrm{nm}$ radius, $12 \mathrm{~nm}$ height) populated with 1000 binding sites and 8000 homogeneously

153 dispersed glutamate molecules. Unbinding and transition rates were converted to probabilities using the

154 following general formula :

$155 P_{i}=k_{i} d t$

156 For receptor current calculation, transmembrane potential was set to $+40 \mathrm{mV}$. AMPA receptor

157 conductance was set to 7, 14 and 20 pS for the di-, tri- and quadri-liganded states, respectively. NMDA

158 receptor conductance was set to $50 \mathrm{pS}$. $\mathrm{I}_{\mathrm{AMPA}}$ was measured at the peak of the response. Depending on

159 the experiment, $\mathrm{I}_{\mathrm{NMDA}}$ was either measured $5 \mathrm{~ms}$ after glutamate release or obtained by averaging

160 current within a $5 \mathrm{~ms}$ duration time window (from 5 to $10 \mathrm{~ms}$ after release) in order to match

161 measurements performed on recorded mEPSCs.

162 RESULTS

163 Variability in mean $I_{N M D A} / I_{A M P A}$ ratio across $N T S$ neurons.

164 Recordings were obtained from a total sample of 43 NTS output neurons (see example in Fig. 1A),

165 among which 20 sent projections to PBN and 23 to the CVLM. Data from the two groups of neurons

166 were pooled after checking that there was no significant difference in main mEPSC characteristics

167 according to the projection site (PBN vs CVLM). The frequency of mEPSCs was highly variable

168 ranging from 0.1 to $1 \mathrm{~Hz}$, depending on the neuron (median : $0.22 \mathrm{~Hz}$ ). At $+40 \mathrm{mV}$, most individual 
169

170

171

172

173

174

175

176

177

178

179

180

181

182

183

184

185

186

187

188

189

190

191

192

193

194

195

196

mEPSCs were composite mEPSCs with both a fast and a slow component attributable to AMPA and NMDA receptor activation $\left(\mathrm{I}_{\mathrm{AMPA}}\right.$ and $\mathrm{I}_{\mathrm{NMDA}}$ ), respectively (Aylwin et al 1997; Balland et al, 2006, 2008, Zhao et al. 2015). We verified that the slow component was suppressed by APV and thus entirely due to NMDA receptor activation (Fig. 1A). Mean $\mathrm{I}_{\mathrm{AMPA}}\left(\mu_{\mathrm{IAMPA}}\right)$ exhibited little variability between cells. Depending on the neuron, it ranged from 14 to $27 \mathrm{pA}$. On the contrary, mean $\mathrm{I}_{\mathrm{NMDA}}\left(\mu_{\mathrm{INMDA}}\right)$ exhibited five-fold variation across neurons, ranging from 2 to $10 \mathrm{pA}$. As a consequence, mean $\mathrm{I}_{\mathrm{NMDA}} / \mathrm{I}_{\mathrm{AMPA}}$ ratio $\left(\mu_{\text {RATIO }}\right)$ was also highly variable across neurons, ranging from 0.12 to 0.49 (Fig 1B).

\section{Variability in quantal events recorded from the same NTS neuron. Fluctuations of $I_{N M D A} / I_{A M P A}$ ratio} mainly result from variations of $I_{N M D A}$

To compare the variabilities of $\mathrm{I}_{\mathrm{NMDA}}, \mathrm{I}_{\mathrm{AMPA}}$ and $\mathrm{I}_{\mathrm{NMDA}} / \mathrm{I}_{\mathrm{AMPA}}$ ratio across $\mathrm{mEPSCs}$ recorded from the same cell we calculated their respective CVs. Intra-neuronal $\mathrm{I}_{\mathrm{NMDA}} / \mathrm{I}_{\mathrm{AMPA}}$ ratio variability was in some cases relatively high with $\mathrm{CV}_{\mathrm{RATIO}}$ values up to 0.94 (range 0.22-0.94, depending on the neuron; Fig 1C). We wondered whether this was due to fluctuations in $\mathrm{I}_{\mathrm{AMPA}}$, or $\mathrm{I}_{\mathrm{NMDA}}$ or both. Whatever the neuron, $\mathrm{CV}_{\text {IAMPA }}$ was low ranging from 0.17 to 0.40 , indicating little fluctuation from one quantal event to the other (Fig. 1C). $\mathrm{I}_{\mathrm{NMDA}}$ was far more variable with $\mathrm{CV}_{\text {INMDA }}$ being up to 0.93 and less than 0.4 for 1 neuron only (Fig. 1C). We concluded that fluctuations in $\mathrm{I}_{\mathrm{NMDA}} / \mathrm{I}_{\mathrm{AMPA}}$ ratio across mEPSCs recorded from the same cell originated from variations in $\mathrm{I}_{\mathrm{NMDA}}$ rather than variations in $\mathrm{I}_{\mathrm{AMPA}}$. This finding was confirmed by regression analysis (coefficients of determination : 0.79 versus 0.02 , respectively; see Fig. 1D,E). We wondered whether high intra-neuronal variability of $\mathrm{I}_{\mathrm{NMDA}}$ as compared to $\mathrm{I}_{\mathrm{AMPA}}$ resulted from differences in receptor channel properties or from stronger variations in NMDA than AMPA receptor content across synapses from the same target cell. To answer this question, we tried to estimate the contribution of stochastic factors to $\mathrm{I}_{\mathrm{NMDA}}$ and $\mathrm{I}_{\mathrm{AMPA}}$ variabilities.

\section{Stochastic factors of $I_{N M D A}$ variability}

Two main stochastic factors may contribute to receptor current variability across mEPSCs: random transitions between receptor channel closed and open states (channel noise) and fluctuations in quantal glutamate release. To estimate $\mathrm{I}_{\mathrm{NMDA}}$ variability resulting from random receptor channel closing and opening, we first calculated channel noise variance according to the binomial distribution. Indeed, if variations of $\mathrm{I}_{\mathrm{NMDA}}$ across mEPSCs were exclusively due to this factor (i.e. no variation in receptor 
number, no variation in neurotransmitter quantum size, instantaneous equilibrium of glutamate concentrations within the cleft), then $\mathrm{I}_{\mathrm{NMDA}}$ would follow a binomial distribution and the resulting variance $\sigma^{2}$ CN should be equal to (Sigworth, 1980 ; Robinson et al., 1991):

$\sigma_{C N}^{2}=i \cdot \mu_{I N M D A}-\frac{\mu_{I N M D A}^{2}}{N}$

201 where $N$ is the number of NMDA receptors and $i$ the unitary receptor current. Since $\mathrm{I}_{\mathrm{NMDA}}$ is the product 202 of the unitary receptor current $i$ by the number of open channels $N P_{o p}\left(P_{o p}\right.$ being the average open 203 probability of NMDA receptors in the synapse), equation 1 may be linearized as follows:

$\sigma_{C N}^{2}=\mu_{I N M D A}\left[i\left(1-P_{o p}\right)\right]$

205 In our experiments, the driving force was set $+40 \mathrm{mV}$. Thus, $i$ was estimated to be about $2 \mathrm{pA}(50 \mathrm{pS}$ 206 unitary conductance for GluN2B-containing NMDA receptors, see Traynelis et al., 2010). Assuming a 207 realistic $P_{o p}$ value of 0.1 (Kessler, 2013), we compared $\mathrm{I}_{\mathrm{NMDA}}$ variances $\left(\sigma_{\text {INMDA }}^{2}\right)$ obtained from recorded 208 neurons with the $\sigma_{\text {CN }}^{2}$ curve calculated from equation 2 (Fig. 2A). It should be kept in mind that $\sigma_{\text {INMDA }}^{2}$ 209 values are likely to have been underestimated since averaging $\mathrm{I}_{\mathrm{NMDA}}$ measurements over 5 ms duration 210 time-window may have resulted in some smoothing of inter-event fluctuations (see methods).

211 Nevertheless, this comparison suggests that a large part of $\mathrm{I}_{\mathrm{NMDA}}$ variability across mEPSCS was 212 accounted for by channel noise.

213 Equation 1 relies on the assumption that every NMDA receptor channel in a synapse has the same $P_{o p}$.

214 This may not be the case since glutamate concentrations decline with distance to the release site. We

215 thus tried to obtain estimates of $\sigma^{2}{ }_{\mathrm{CN}}$ that take into account possible differences in $P_{o p}$ between receptors 216 according to their location relative to the release site. This was done by computer simulation using a 217 Monte Carlo model of a glutamatergic synapse. Simulation was performed in 10 series of 50 runs each, 218 each run representing a different quantal event. The amount of glutamate released was held constant 219 (3000 molecules) throughout runs and series. The number of NMDA receptors in the synapse was 220 adjusted between series (from 10 to 100 ) in order to span the entire range of mean $\mathrm{I}_{\mathrm{NMDA}}$ values obtained 221 from recorded neurons. $\mathrm{I}_{\mathrm{NMDA}}$ values were measured $5 \mathrm{~ms}$ after onset. We compared $\sigma_{\text {INMDA }}^{2}$ obtained by 222 simulation with the $\sigma^{2}$ CN curve calculated from equation 2 using the average $P_{o p}$ value of NMDA 
223 receptors in simulated data (0.07). The fit between the theoretical curve and the simulated data was

224 nearly perfect (Fig. 2B) indicating that binomial distribution based on an averaged $P_{o p}$ provides an

225 accurate description of the stochastic behavior of synaptic NMDA receptors.

226 We next used computer simulation to get estimate of $\mathrm{I}_{\mathrm{NMDA}}$ variability resulting from fluctuations in

227 glutamate release. Simulation was performed using a randomly determined amount of glutamate

228 released for each run (see methods). The within-series average was close to 3000 glutamate molecules

229 with either a low $\left(\mathrm{CV}_{\mathrm{Glu}}\right.$ ranging from 0.26 to 0.31 , depending on the series $)$ or a high $\left(\mathrm{CV}_{\mathrm{Glu}}\right.$ ranging

230 from 0.50 to 0.62 , depending on the series) variability. Surprisingly, we found little difference between

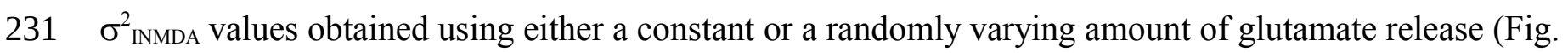

232 2C,D) suggesting that the part of $\mathrm{I}_{\mathrm{NMDA}}$ variability resulting from release fluctuations is small as

233 compared to that resulting from channel noise. This finding may seem at odds with the current view

234 which states that channel noise minimally contribute to quantal current variability. This view was

235 mainly based on studies dealing with $\mathrm{I}_{\text {AMPA }}$ variability (see for instance Franks et al., 2002 ; 2003). We

236 therefore compared the stochastic behavior of AMPA and NMDA receptors placed in identical

237 conditions.

\section{Comparison between $I_{N M D A}$ and $I_{A M P A}$ stochastic behavior}

239 Simulation was performed with 100 NMDA receptors and 100 AMPA receptors in the PSD. A first

240 series was obtained with a constant amount of glutamate release throughout runs. Subsequent series

241 were obtained with randomly determined numbers of glutamate molecules released (series average $\approx$

242 3000), using parameters adjusted in order to obtain low, moderate or high release variability $\left(\mathrm{CV}_{\mathrm{Glu}}: 0.3\right.$,

2430.54 and 0.62 , respectively). To allow comparison between $\mathrm{I}_{\mathrm{NMDA}}$ and $\mathrm{I}_{\mathrm{AMPA}}$, variances were converted

244 into $C V s$. We found that contrary to $\mathrm{CV}_{\text {INMDA }}, \mathrm{CV}_{\text {IAMPA }}$ was very low using constant release and steeply

245 increased with $\mathrm{CV}_{\mathrm{Glu}}$ (Fig. 3A,B). Plotting individual currents values within a series against the amount

246 of glutamate released illustrated the different behaviors of the two receptors (Fig. 3C,D). While $\mathrm{I}_{\mathrm{AMPA}}$

247 amplitudes were strongly correlated with release (coefficient of determination : 0.77), $\mathrm{I}_{\mathrm{NMDA}}$ amplitudes

248 were only loosely correlated with glutamate molecules numbers (coefficient of determination : 0.21). A

249 first factor that may explain this difference is the fact that AMPA receptors had an higher average open

250 probability than NMDA receptors. In addition, AMPA receptors have subconductance states that depend 
251 on the number of bound glutamate molecules (Traynelis et al. 2010). It should be kept in mind that

252 equation 2 derives from the binomial distribution and applies to channels that exist in conducting and

253 non-conducting states only, a more complex mathematical description being required for channels with

254 subconductance states, (see Neher and Stevens, 1977). Accordingly, we showed that removing the

255 partially-conducting states (i.e., the di and tri-liganded states) in the AMPA receptor scheme increased

$256 \mathrm{I}_{\mathrm{AMPA}}$ variability to levels expected from equation 2, indicating that the presence of subconductance

257 states decreases channel noise (Fig. 3E). Noise reduction by subconductance states was substantial as

258 shown by the two-third decrease in variance. Taken as a whole these data point out the fact that,

259 contrary to $\mathrm{I}_{\mathrm{NMDA}}$ variability which mainly results from receptor noise, $\mathrm{I}_{\mathrm{AMPA}}$ variability at a single

260 synapse tightly reflects fluctuations in glutamate release. These differences between AMPA and NMDA

261 receptor behaviors may have contributed to the variability of the $\mathrm{I}_{\mathrm{NMDA}} / \mathrm{I}_{\mathrm{AMPA}}$ ratio across $\mathrm{mEPSCs}$

262 recorded from the same cell.

\section{The origin of of $I_{N M D A} / I_{A M P A}$ ratio variability in quantal events recorded from NTS neuron}

264 We next wondered what would be $\mathrm{I}_{\mathrm{NMDA}} / \mathrm{I}_{\mathrm{AMPA}}$ ratio variability if there were no difference in

265 NMDA/AMPA receptor proportions between synapses onto the same target cell. We estimated $\sigma_{\text {Ratio }}^{2}$ by 266 using first the order Taylor expansion (van Kempen and van Vliet, 2000):

$\sigma_{\text {Ratio }}^{2} \approx \frac{\mu_{I N M D A}^{2}}{\mu_{\text {IAMPA }}^{2}}\left[\frac{\sigma_{I N M D A}^{2}}{\mu_{I N M D A}^{2}}+\frac{\sigma_{\text {IAMPA }}^{2}}{\mu_{\text {IAMPA }}^{2}}-\frac{2 \rho_{(I N M D A, I A M P A)} \sigma_{I N M D A} \sigma_{I A M P A}}{\mu_{N M D A} \mu_{I A M P A}}\right]$

268 where $\rho_{\text {(INMDA,IAMPA) }}$ is the correlation coefficient between $\mathrm{I}_{\mathrm{NMDA}}$ and $\mathrm{I}_{\mathrm{AMPA}}$. Since $\mathrm{I}_{\mathrm{NMDA}} / \mathrm{I}_{\mathrm{AMPA}}$ ratio

269 variability was primarily due to variations in $\mathrm{I}_{\mathrm{NMDA}}$ (see Fig. 1E), we reasoned that receptor ratio

270 heterogeneity across synapses, if present, would primarily result in increased $\mathrm{I}_{\mathrm{NMDA}}$ fluctuation. Thus, to

271 eliminate potential effects of synapses heterogeneity, we replaced $\sigma_{\text {INMDA }}^{2}$ and $\sigma_{\text {INMDA }}$ in equation 3 by $\sigma$

$272{ }^{2} \mathrm{CN}$ and $\sigma_{\mathrm{CN}}$ values obtained from equation 2 :

273

$$
\sigma_{\text {Ratio }}^{2} \approx \frac{\mu_{\text {INMDA }}^{2}}{\mu_{\text {IAMPA }}^{2}}\left[\frac{i\left(1-P_{o p}\right)}{\mu_{\text {INMDA }}}+\frac{\sigma_{\text {IAMPA }}^{2}}{\mu_{\text {IAMPA }}^{2}}-\frac{2 \sqrt{i\left(1-P_{o p}\right)} \rho_{(I N M D A, I A M P A)} \sigma_{\text {IAMPA }}}{\sqrt{\mu_{N M D A}}}\right]
$$

274 Calculation was performed for each neuron using the experimentally obtained values for $\mu_{\mathrm{INMDA}}, \mu_{\mathrm{IAMPA}}$,

$275 \sigma_{\text {IAMPA }}^{2}$ and $\rho_{\text {(INMDA,IAMPA) }}$. Comparing $\sigma_{\text {Ratio }}^{2}$ values directly obtained from recorded data and those 
275 recalculated from equation 4 showed that the observed $\mathrm{I}_{\mathrm{NMDA}} / \mathrm{I}_{\mathrm{AMPA}}$ ratio variability was largely

276 attributable to stochastic factors (Fig. 4A,B). Especially, the slope of the regression line of recorded

277 values on calculated values was close to 1 (Fig. 4B) indicating that experimentally observed variability

278 was on average close to that expected if $\mathrm{I}_{\mathrm{NMDA}}$ fluctuations were entirely due to channel noise.

279 To confirm this finding, we performed simulation according to two scenarios, one assuming that the 280 ratio of NMDA to AMPA receptors at synapses varies between neurons but is strictly identical across

281 the different synapses onto the same neuron (scenario 1, Fig. 4C), the other assuming that the relative 282 abundance of AMPA and NMDA receptors at synapses depends on the afferent pathway only and thus

283 differs between synapses onto the same target cell (scenario 2, Fig 4E). Each neuron was simulated by a 284 series of 50 runs, each run representing a quantal event occurring at a different synapse. The numbers of 285 AMPA and NMDA receptors in the simulation were adjusted in order to fit the averaged quantal 286 currents recorded in actual NTS neurons. We kept the AMPA receptor number constant (100 per 287 synapse) across simulated neurons and we adjusted the overall number of NMDA receptors neuron by

288 neuron in order to span the entire range of $\mu_{\mathrm{INMDA}}$ values found in recorded cells. Release variability was 289 adjusted $\left(\mathrm{CV}_{\mathrm{Glu}} \approx 0.3\right)$ in order to obtain $\sigma_{\text {IAMPA }}^{2}$ close to those calculated for recorded neurons. $\mathrm{I}_{\mathrm{NMDA}}$ 290 value was obtained by averaging current over a $5 \mathrm{~ms}$ time windows (see methods).

291 We then plotted $\sigma_{\text {Ratio }}^{2}$ values obtained from either recorded or simulated neurons against $\mu_{\mathrm{INMDA}}$.

292 Variances measured from recorded mEPSCs were very close to values provided by simulation using 293 scenario 1 (Fig. 4D) and far below those obtained using scenario 2 (Fig. 4F), confirming that the 294 variability of the $\mathrm{I}_{\mathrm{NMDA}} / \mathrm{I}_{\mathrm{AMPA}}$ ratio found in mEPSCs recorded from the same cell resulted from channel 295 noise and fluctuations in glutamate release rather than from heterogeneity of receptor ratio across 296 synapses.

297 Correlation between $I_{N M D A}$ and $I_{A M P A}$ across $m E P S C$ from the same neuron

298 We wondered whether a similar NMDA to AMPA receptor ratio across a neuron's synapses would 299 invariably result in a strong correlation between $\mathrm{I}_{\mathrm{NMDA}}$ and $\mathrm{I}_{\mathrm{AMPA}}$ in mEPSCs. Even with fully-identical 300 receptor ratio, one may expect the correlation to vanish if NMDA channel noise is high enough. Signal 301 to noise ratio (SNR) calculated from the binomial distribution is equal to: 
$S N R=\sqrt{\frac{N \cdot P_{o p}}{\left[\left(1-P_{o p}\right)\right]}}$

303 We reasoned that, since SNR increases with the square root of the receptor number $N$, the strength of

304 the correlation between $\mathrm{I}_{\mathrm{NMDA}}$ and $\mathrm{I}_{\mathrm{AMPA}}$ should likewise increase with NMDA receptor number. We first

305 look at quantal events simulated using scenario 1. We found a significant correlation between $\mathrm{I}_{\mathrm{NMDA}}$ and $306 \mathrm{I}_{\mathrm{AMPA}}$ for most but not all simulated neurons. Furthermore, the strength of the correlation was highly

307 variable (see examples in Fig. 5A). For the 27 neurons simulated using scenario 1, Pearson $r$

308 coefficients ranged from 0.14 to 0.65 . As expected, correlation strength was found to linearly increase

309 with receptor number in synapses (the only changing parameter between neurons in scenario 1) and

310 hence with $\mu_{\text {INMDA }}$ (Fig. 5B). We next examined recorded neurons. Most but not all (34 out 43)

311 exhibited significant correlation between $\mathrm{I}_{\mathrm{NMDA}}$ and $\mathrm{I}_{\mathrm{AMPA}}$ (see example in Fig 5C). Pearson r coefficients

312 ranged from 0.27 to 0.89 and increased with $\mu_{\mathrm{INMDA}}$ (Fig 5D), consistent with the view that loose or

313 lacking correlation resulted from high relative NMDA channel noise rather than synapses heterogeneity.

\section{DISCUSSION}

315 Here we found that quantal events recorded from the same NTS projection neuron exhibited substantial 316 variations in $\mathrm{I}_{\mathrm{NMDA}} / \mathrm{I}_{\mathrm{AMPA}}$ ratio. Using both a theoretical approach and numerical simulation, we showed

317 that variability of $\mathrm{I}_{\mathrm{NMDA}} / \mathrm{I}_{\mathrm{AMPA}}$ ratio was mostly if not entirely explainable by two factors: i) channel noise 318 being especially strong at NMDA receptors, and ii) fluctuations in glutamate release having stronger

319 effects on $\mathrm{I}_{\mathrm{AMPA}}$ than on $\mathrm{I}_{\mathrm{NMDA}}$. These findings rule out any substantial contribution of synapse

320 heterogeneity to the variability of $\mathrm{I}_{\mathrm{NMDA}} / \mathrm{I}_{\mathrm{AMPA}}$ ratio. They therefore imply that the proportions of AMPA 321 and NMDA receptors was similar, or roughly similar, across synapses onto the same target cell. In 322 addition, we found strong differences in mean $\mathrm{I}_{\mathrm{NMDA}} / \mathrm{I}_{\mathrm{AMPA}}$ ratio between neurons. Thus, our results 323 support the idea that the receptor ratio in synapses is determined by the target cell rather than the 324 afferent pathway. This conclusion is reminiscent of previous findings showing that different synapses 325 onto the same neocortical neuron have very similar NMDA to AMPA receptor ratios (Umemiya et al., 326 1999; Watt et al., 2000; Myme et al., 2003; Watt et al., 2004) and raises the question of whether 327 mechanisms exist that co-regulate AMPA and NMDA receptor expression in postsynaptic membranes. 
328 As yet, AMPA and NMDA receptor trafficking are viewed as independent processes. To the best of our 329 knowledge, there is no evidence for co-transport of AMPA and NMDA receptors through secretory or 330 endosomal recycling pathways. Likewise, there is no data suggesting that AMPA and NMDA

331 insertion/stabilization in postsynaptic membrane are tightly linked to each other. Alternatively, a

332 conserved receptor ratio across synapses may be the passive consequence of structural constraints.

333 Electron microscope studies performed in various CNS regions using either post-embeding

334 immunogold labeling, freeze fracture replica immunolabeling or STEM tomography indicate that the

335 number of AMPA receptors in synaptic clusters linearly scales with PSD size (Takumi et al., 1999;

336 Racca et al., 2000; Tanaka et al., 2005; Masugi-Tokita et al., 2007; Antal et al., 2008; Shinohara et al., 337 2008; Dong et al., 2010; Rubio et al., 2014; Chen et al., 2015). NMDA receptor number in synaptic

338 clusters also correlates with PSD size in several brain areas (Racca et al., 2000; Nyiri et al., 2003;

339 Tarusawa et al., 2009; Rubio et al., 2014; but see Takumi et al., 1999; Shinohara et al., 2008; Chen et

340 al., 2015). Thus, it may be hypothesized that the postsynaptic membrane includes finite numbers of

341 specific potential slots for AMPA and NMDA receptors and that the number of slots for each receptor

342 linearly scales with the PSD area. The slot hypothesis was originally proposed to explain how synapses

343 acquire additional AMPA receptors during postsynaptic LTP (Shi et al., 2001; see also Lisman and

344 Raghavachari, 2006; Opazo et al., 2012). It was also postulated that potential slots are not always fully

345 filled with receptors. In this context, a possible interpretation for our data is that the degree of filling of

346 potential NMDA slots is similar across a NTS neuron's synapses but differs between NTS neurons,

347 presumably because of differences in readily available extrasynaptic receptors pools.

348 An unexpected finding from our simulation experiments was the fact that $\mathrm{I}_{\mathrm{NMDA}}$ and $\mathrm{I}_{\mathrm{AMPA}}$ fluctuations

349 across mEPSCs originated from different sources. $\mathrm{I}_{\mathrm{NMDA}}$ variability was mainly postsynaptic as it

350 resulted from strong channel noise overwhelming the influence of release variations. On the contrary,

351 AMPA receptor channel noise was low and $\mathrm{I}_{\mathrm{AMPA}}$ variability was mainly presynaptic, tightly reflecting

352 variations in the amount of glutamate released. The lower variability of $\mathrm{I}_{\mathrm{AMPA}}$ as compared to $\mathrm{I}_{\mathrm{NMDA}}$ as

353 observed in the present study both in vivo and in silico is in line with previous results obtained by

354 single synapse recording on hippocampal cell cultures (McAllister and Stevens, 2000). Data in Table 1

355 from McAllister and Stevens (2000) indicate that the CV of the AMPA component across responses 
356 from a single synapse ranged between 0.27 and 0.43 , depending on the synapse, while the CV of the

357 NMDA component across the same responses ranged between 0.56 and 0.82 , depending on the synapse.

358 It has been claimed previously that differences between the variability of AMPAR and NMDAR

359 responses were due solely to unequal numbers of receptors at the synapse (Franck et al., 2002 ; 2003 ).

360 This claim was based on simulations performed with simplified kinetic schemes including few receptor

361 states (Lester and Jahr, 1992 for NMDA receptors and Jonas et al, 1993 for AMPA receptors). Here,

362 using recently published more realistic Markov models (Roberts et al, 2005 for AMPA receptors and

363 Erreger et al. 2005 for NMDA receptors), we unraveled an unexpected biophysical difference between

364 the two receptors. We found that the intrinsic noise of AMPA channels is lower than that of NMDA

365 channels partly as a consequence of AMPA receptors having subconductance states. In addition, the

366 gradual opening of the AMPA receptor pore with the number of bound glutamate molecules provides a

367 mechanism by wich unitary receptor current increases with cleft glutamate concentration. In conclusion,

368 our data show that AMPA receptors are endowed with specific features that reduce the variability of the

369 early as compare to the late NMDA receptor-dependent phase of the postsynaptic response. From a

370 functional point of view, these AMPA receptor specific features may fulfill an important role by

371 increasing the temporal precision and the reliability of fast excitatory transmission.

373 Acknowledgments. We wish to think Dr Lydia Kerkerian and Dr Francis Castets for their helpful

374 comments on the manuscript. We also express our gratitude to Dr Boris Barbour for judicious advice in 375 early steps of the study. 


\section{References}

377 Antal M, Fukazawa Y, Eördögh M, Muszil D, Molnár E, Itakura M, Takahashi M, Shigemoto R (2008)

378 Numbers, densities, and colocalization of AMPA- and NMDA-type glutamate receptors at individual

379 synapses in the superficial spinal dorsal horn of rats. J Neurosci 28:9692-96701.

380 Aylwin ML, Horowitz JM, Bonham AC (1997) NMDA receptors contribute to primary visceral afferent 381 transmission in the nucleus of the solitary tract. J Neurophysiol May;77(5):2539-2548.

382 Balland B, Lachamp P, Strube C, Kessler JP, Tell F (2006) Glutamatergic synapses in the rat nucleus 383 tractus solitarii develop by direct insertion of calcium-impermeable AMPA receptors and without 384 activation of NMDA receptors. J Physiol. 574:245-261.

385 Balland B, Lachamp P, Kessler JP, Tell F (2008) Silent synapses in developing rat nucleus tractus 386 solitarii have AMPA receptors. J Neurosci 28 :4624-4634.

387 Baude A, Strube C, Tell F, Kessler JP (2009) Glutamatergic neurotransmission in the nucleus tractus 388 solitarii: structural and functional characteristics. J Chem Neuroanat 38:145-153.

389 Chen X, Levy JM, Hou A, Winters C, Azzam R, Sousa AA, Leapman RD, Nicoll RA, Reese TS (2015) 390 PSD-95 family MAGUKs are essential for anchoring AMPA and NMDA receptor complexes at the 391 postsynaptic density. Proc Natl Acad Sci U S A 112:E6983-6992.

392 Deleuze C, Huguenard JR (2016) Two classes of excitatory synaptic responses in rat thalamic reticular 393 neurons. J Neurophysiol.116:995-1011.

394 Dong YL, Fukazawa Y, Wang W, Kamasawa N, Shigemoto R (2010) Differential postsynaptic 395 compartments in the laterocapsular division of the central nucleus of amygdala for afferents from the 396 parabrachial nucleus and the basolateral nucleus in the rat. J Comp Neurol 518:4771-91.

397 Ellender TJ, Harwood J, Kosillo P, Capogna M, Bolam JP (2013) Heterogeneous properties of central

398 lateral and parafascicular thalamic synapses in the striatum. J Physiol 591:257-72. 
399 Erreger K, Dravid SM, Banke TG, Wyllie DJ, Traynelis SF (2005) Subunit-specific gating controls rat

400 NR1/NR2A and NR1/NR2B NMDA channel kinetics and synaptic signalling profiles. J Physiol

$401 \quad 563: 345-358$.

402 Franks KM, Bartol TM Jr, Sejnowski TJ (2002)A Monte Carlo model reveals independent signaling at 403 central glutamatergic synapses. Biophys J. 83:2333-2348.

404 Franks KM, Stevens CF, Sejnowski TJ (2003) Independent sources of quantal variability at single 405 glutamatergic synapses. J Neurosci. 23:3186-3195.

406 Fukazawa Y, Shigemoto R (2012) Intra-synapse-type and inter-synapse-type relationships between 407 synaptic size and AMPAR expression. Curr Opin Neurobiol 22:446-452.

408 Gomperts SN, Rao A, Craig AM, Malenka RC, Nicoll RA (1998) Postsynaptically silent synapses in 409 single neuron cultures. Neuron 21:1443-1451.

410 Hanse E, Gustafsson B (2000) Quantal variability at glutamatergic synapses in area CA1 of the rat 411 neonatal hippocampus. J Physiol. 531:467-480.

412 Jonas P, Major G, Sakmann B (1993) Quantal components of unitary EPSCs at the mossy fibre synapse 413 on CA3 pyramidal cells of rat hippocampus. J Physiol. 472:615-663.

414 Kessler JP (2013) Control of cleft glutamate concentration and glutamate spill-out by perisynaptic glia: 415 uptake and diffusion barriers. PLoS One 8:e70791.

416 Lester RA, Jahr CE (1992) NMDA channel behavior depends on agonist affinity. J Neurosci. $417 \quad 12: 635-43$.

418 Lisman J, Raghavachari S (2006) A unified model of the presynaptic and postsynaptic changes during 419 LTP at CA1 synapses. Sci STKE 356:re11.

420 Masugi-Tokita M, Tarusawa E, Watanabe M, Molnár E, Fujimoto K, Shigemoto R (2007) Number and 421 density of AMPA receptors in individual synapses in the rat cerebellum as revealed by SDS-digested 422 freeze-fracture replica labeling. J Neurosci 27:2135-2144. 
423 McAllister AK, Stevens CF 2000). Nonsaturation of AMPA and NMDA receptors at hippocampal synapses. Proc Natl Acad Sci U S A. 97:6173-6178.

425 Myme CI, Sugino K, Turrigiano GG, Nelson SB (2003) The NMDA-to-AMPA ratio at synapses onto 426 layer 2/3 pyramidal neurons is conserved across prefrontal and visual cortices. J. Neurophysiol 90:771$427 \quad 779$

428 Neher E, Stevens CF. Conductance fluctuations and ionic pores in membranes (1977) Annu Rev 429 Biophys Bioeng. 6:345-381.

430 Nusser Z, Lujan R, Laube G, Roberts JD, Molnar E, Somogyi P (1998) Cell type and pathway 431 dependence of synaptic AMPA receptor number and variability in the hippocampus. Neuron 21:545432559.

433 Nyíri G, Stephenson FA, Freund TF, Somogyi P (2003). Large variability in synaptic N-methyl-D434 aspartate receptor density on interneurons and a comparison with pyramidal-cell spines in the rat 435 hippocampus. Neuroscience 119:347-63.

436 Opazo P, Sainlos M, Choquet D (2012) Regulation of AMPA receptor surface diffusion by PSD-95 437 slots. Curr Opin Neurobiol 22:453-460.

438 Otmakhova NA, Otmakhov N, Lisman JE (2002) Pathway-specific properties of AMPA and NMDA439 mediated transmission in CA1 hippocampal pyramidal cells. J Neurosci 22:1199-207.

440 Racca C, Stephenson FA, Streit P, Roberts JD, Somogyi P (2000) NMDA receptor content of synapses 441 in stratum radiatum of the hippocampal CA1 area. J Neurosci 20:2512-2522.

442 Robert A, Armstrong N, Gouaux JE, Howe JR (2005) AMPA receptor binding cleft mutations that alter 443 affinity, efficacy, and recovery from desensitization. J Neurosci 25:3752-3762.

444 Robinson HP, Sahara Y, Kawai N (1991) Nonstationary fluctuation analysis and direct resolution of 445 single channel currents at postsynaptic sites. Biophys J. 1991 59:295-304.

446 Rubio ME, Fukazawa Y, Kamasawa N, Clarkson C, Molnár E, Shigemoto R (2014) Target- and input- 
447 dependent organization of AMPA and NMDA receptors in synaptic connections of the cochlear nucleus. 448 J Comp Neurol 522:4023-42.

449 Santucci DM, Raghavachari S (2008) The effects of NR2 subunit-dependent NMDA receptor kinetics 450 on synaptic transmission and CaMKII activation. PLoS Comput Biol. 4:e1000208.

451 Shi S, Hayashi Y, Esteban JA, Malinow R (2001) Subunit-specific rules governing AMPA receptor 452 trafficking to synapses in hippocampal pyramidal neurons. Cell 105:331-343.

453 Shinohara Y, Hirase H, Watanabe M, Itakura M, Takahashi M, Shigemoto R (2008) Left-right

454 asymmetry of the hippocampal synapses with differential subunit allocation of glutamate receptors.

455 Proc Natl Acad Sci U S A. 105:19498-19503.

456 Sigworth FJ (1980) The variance of sodium current fluctuations at the node of Ranvier. J Physiol. $457 \quad 307: 97-129$.

458 Smeal RM, Keefe KA, Wilcox KS (2008) Differences in excitatory transmission between thalamic and 459 cortical afferents to single spiny efferent neurons of rat dorsal striatum. Eur J Neurosci 28:2041-2052.

460 Strube C, Saliba L, Moubarak E, Penalba V, Martin-Eauclaire MF, Tell F, Clerc N (2015) Kv4 channels 461 underlie A-currents with highly variable inactivation time courses but homogeneous other gating 462 properties in the nucleus tractus solitarii. Pflugers Arch 467:789-803.

463 Takumi Y, Ramírez-León V, Laake P, Rinvik E, Ottersen OP (1999) Different modes of expression of 464 AMPA and NMDA receptors in hippocampal synapses. Nat Neurosci 2:618-24.

465 Tanaka J, Matsuzaki M, Tarusawa E, Momiyama A, Molnar E, Kasai H, Shigemoto R (2005) Number 466 and density of AMPA receptors in single synapses in immature cerebellum. J Neurosci 25:799-807.

467 Tarusawa E, Matsui K, Budisantoso T, Molnár E, Watanabe M, Matsui M, Fukazawa Y, Shigemoto R 468 (2009) Input-specific intrasynaptic arrangements of ionotropic glutamate receptors and their impact on 469 postsynaptic responses. J Neurosci 29:12896-12908. 
470 Traynelis SF, Wollmuth LP, McBain CJ, Menniti FS, Vance KM, Ogden KK, Hansen KB, Yuan H,

471 Myers SJ, Dingledine R (2010)Glutamate receptor ion channels: structure, regulation, and function.

472 Pharmacol Rev. 62:405-496.

473 Turrigiano GG (2000) AMPA receptors unbound: membrane cycling and synaptic plasticity. Neuron.

$474 \quad 26: 5-8$.

475 Umemiya M, Senda M, and Murphy TH (1999) Behaviour of NMDA and AMPA receptor-mediated

476 miniature EPSCs at rat cortical neuron synapses identified by calcium imaging. J Physiol 521:113-122.

477 van Kempen GM, van Vliet LJ (2000) Mean and variance of ratio estimators used in fluorescence ratio 478 imaging. Cytometry. $39: 300-305$.

479 Watt AJ, van Rossum MC, MacLeod KM, Nelson SB, Turrigiano GG (2000) Activity coregulates

480 quantal AMPA and NMDA currents at neocortical synapses. Neuron 26:659-670.

481 Watt AJ, Sjöström PJ, Häusser M, Nelson SB, Turrigiano GG (2004) A proportional but slower NMDA 482 potentiation follows AMPA potentiation in LTP. Nat Neurosci. 7:518-24.

483 Yang Y, Xu-Friedman MA (2015) Different pools of glutamate receptors mediate sensitivity to ambient 484 glutamate in the cochlear nucleus. J Neurophysiol 113:3634-3645.2015

485 Zhao H, Peters JH, Zhu M, Page SJ, Ritter RC, Appleyard SM (2015) Frequency-dependent facilitation 486 of synaptic throughput via postsynaptic NMDA receptors in the nucleus of the solitary tract. J Physiol ; 487 593:111-125. 


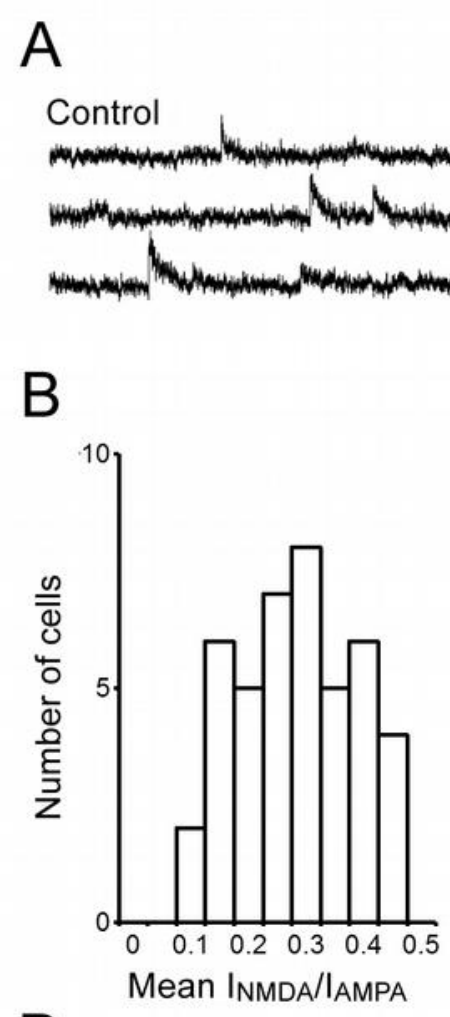

C

$\mathrm{D}$

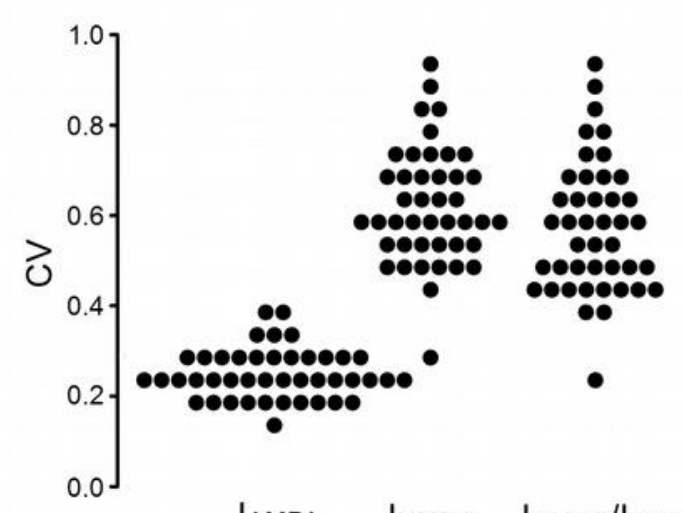

IAMPA INMDA INMDA/IAMPA

$E$
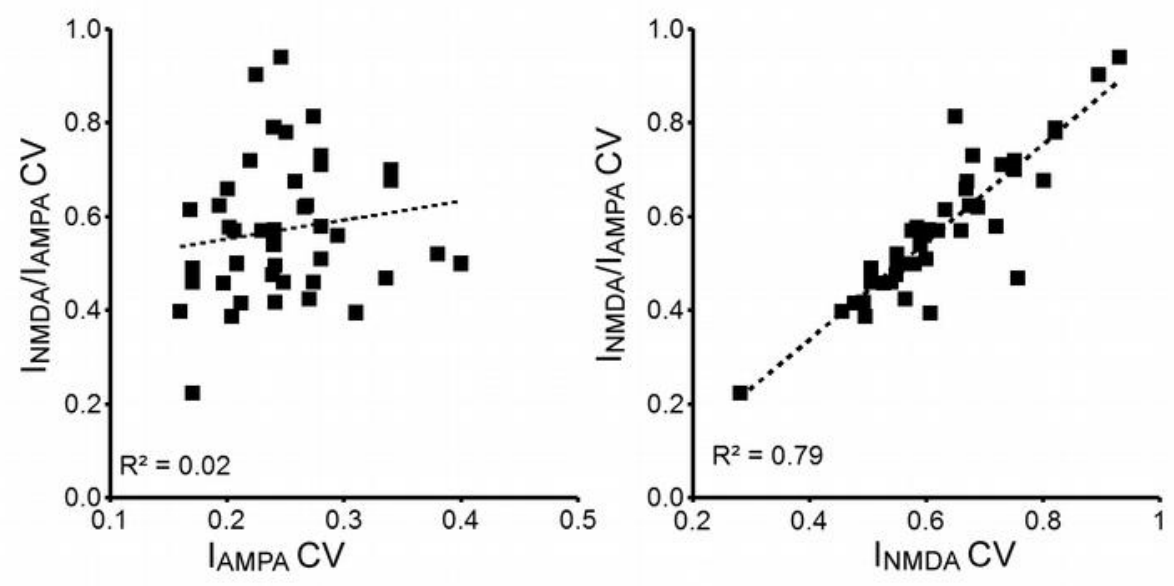

489 Figure 1. A. Example of recordings obtained from an NTS neuron (holding potential $+40 \mathrm{mV}$ ). The

490 slow component of composites mEPSC recorded in control conditions is no longer present when D,L-

491 APV is added to perfusion medium $(100 \mu \mathrm{M})$ indicating that it is entirely due to NMDA receptors. $\mathbf{B}$.

492 Distribution histogram of mean $\mathrm{I}_{\mathrm{NMDA}} / \mathrm{I}_{\mathrm{AMPA}}$ ratios $\left(\mu_{\mathrm{RATI}}\right)$ in mEPSCs from recorded neurons $(\mathrm{n}=43)$. $\mathbf{C}$. 
493 Distribution histograms of $\mathrm{I}_{\mathrm{AMPA}}, \mathrm{I}_{\mathrm{NMDA}}$ and $\mathrm{I}_{\mathrm{NMDA}} / \mathrm{I}_{\mathrm{AMPA}}$ ratio coefficients of variation $(\mathrm{CV})$ in $\mathrm{mEPSCs}$

494 from recorded neurons. D. Lack of correlation between $\mathrm{I}_{\mathrm{AMPA}}$ and $\mathrm{I}_{\mathrm{NMDA}} / \mathrm{I}_{\mathrm{AMPA}}$ ratio CVs across recorded

495 neurons. E. $\mathrm{I}_{\mathrm{NMDA}} / \mathrm{I}_{\mathrm{AMPA}}$ ratio $\mathrm{CV}$ in mEPSCs from recorded neurons linearly increases with $\mathrm{I}_{\mathrm{NMDA}} \mathrm{CV}$

$496\left(\mathrm{R}^{2}\right.$ : coefficient of determination). 

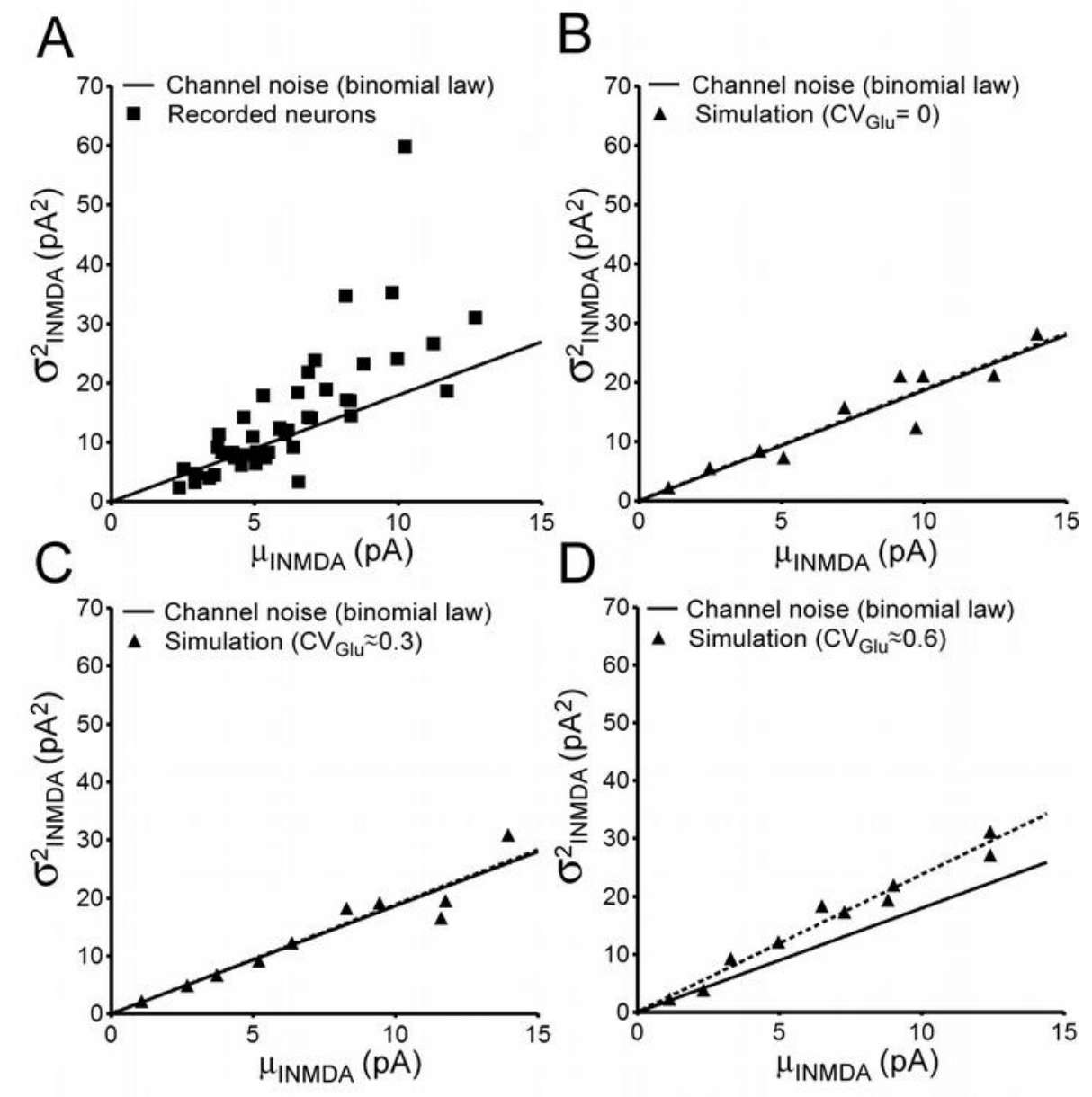

497 Figure 2.A. $\mathrm{I}_{\mathrm{NMDA}}$ variance $\left(\sigma_{\text {INMDA }}^{2}\right)$ across mEPSCs of recorded neurons as a function of mean $\mathrm{I}_{\mathrm{NMDA}}$.

498 The solid line corresponds to NMDA receptor channel noise values predicted by equation 2 using a 50

$499 \mathrm{pS}$ conductance and a $0.1 \mathrm{P}_{\mathrm{op}}$ value. B. $\mathrm{I}_{\mathrm{NMDA}}$ variance in simulated mEPSCs series as a function of

500 mean $\mathrm{I}_{\mathrm{NMDA}}$. Each data point represents a different mEPSCs series. Data were obtained using a constant

501 amount of glutamate released (3000 molecules per quantal event). Note that the regression line of

502 simulation values (dashed line) perfectly fits with NMDA receptor channel noise values predicted by

503 equation 2 (solid line). C and D. As in B, except that the amount of glutamate released (3000

504 molecules per quantal event on average for each series ) was made variable from one quantal event to

505 the other within each simulated mEPSCs series. The coefficient of variation of glutamate released was

506 comprised between 0.26 and 0.31 in $\mathrm{C}$ and between 0.50 and 0.62 in D. 

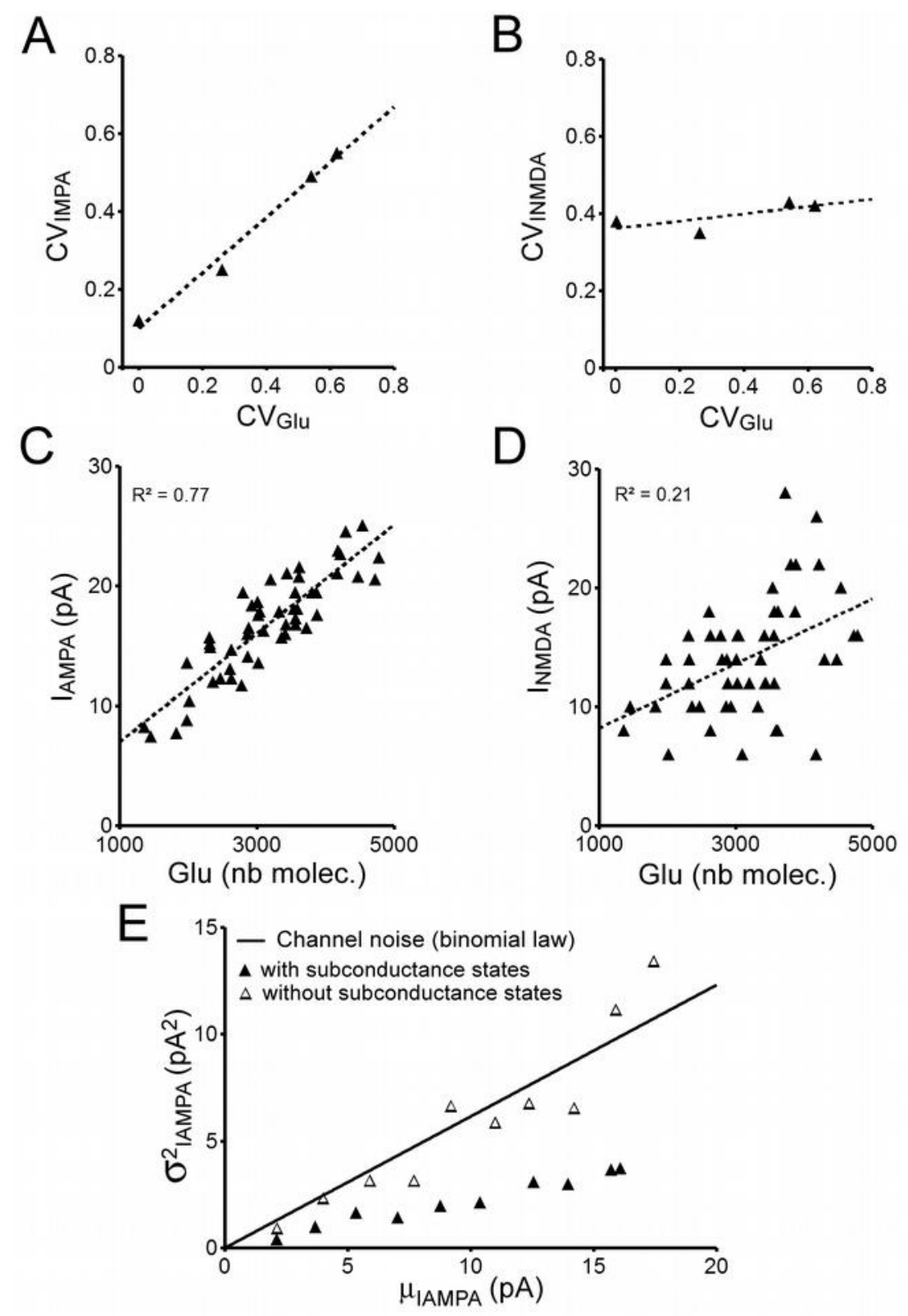

507 Figure 3. A and B. The influence of fluctuations in glutamate release on $\mathrm{I}_{\mathrm{AMPA}}$ and $\mathrm{I}_{\mathrm{NMDA}}$ variability.

508 Each data point represents the $\mathrm{CV}$ of $\mathrm{I}_{\mathrm{AMPA}}(\mathrm{A})$ or $\mathrm{I}_{\mathrm{NMDA}}(\mathrm{B})$ within a series of simulated mEPSCs

509 obtained with 100 AMPA receptors and 100 NMDA receptors and a fixed level of fluctuations in

510 glutamate release. Note the strong correlation between $\mathrm{CV}_{\text {IAMPA }}$ and $\mathrm{CV}_{\mathrm{GLU}}$ and the lack of influence of

$511 \mathrm{CV}_{\mathrm{GLU}}$ on $\mathrm{CV}_{\mathrm{INMDA}}$. C and D. $\mathrm{I}_{\mathrm{AMPA}}(\mathrm{C})$ an $\mathrm{I}_{\mathrm{NMDA}}$ (D) values in individual simulated mEPSCs plotted

512 against the amount of glutamate release. Note that the relationship with the number of glutamate

513 molecules released is strong for $\mathrm{I}_{\mathrm{AMPA}}$ and considerably weaker for $\mathrm{I}_{\mathrm{NMDA}}$. E. $\mathrm{I}_{\mathrm{AMPA}}$ variance in simulated 
514 mEPSCs series obtained using a constant amount of glutamate released (3000 molecules per quantal

515 event). Each data point represents a different mEPSCs series obtained using either the kinetic scheme

516 from Robert et al. (2005) which includes a $20 \mathrm{pS}$ conductance state and 7 and $14 \mathrm{pS}$ subconductance

517 states (solid triangles) or a simplified kinetic scheme including a single $20 \mathrm{pS}$ conductance state (empty

518 triangles). The solid line corresponds to AMPA receptor channel noise values predicted by equation 2

519 using a $20 \mathrm{pS}$ conductance and a $0.23 \mathrm{P}_{\text {op }}$ value. Note that subconductance states result in decreased

$520 \mathrm{I}_{\mathrm{AMPA}}$ variance as compared to both expected channel noise and simulation values obtained using the

521 simplified kinetic scheme. 

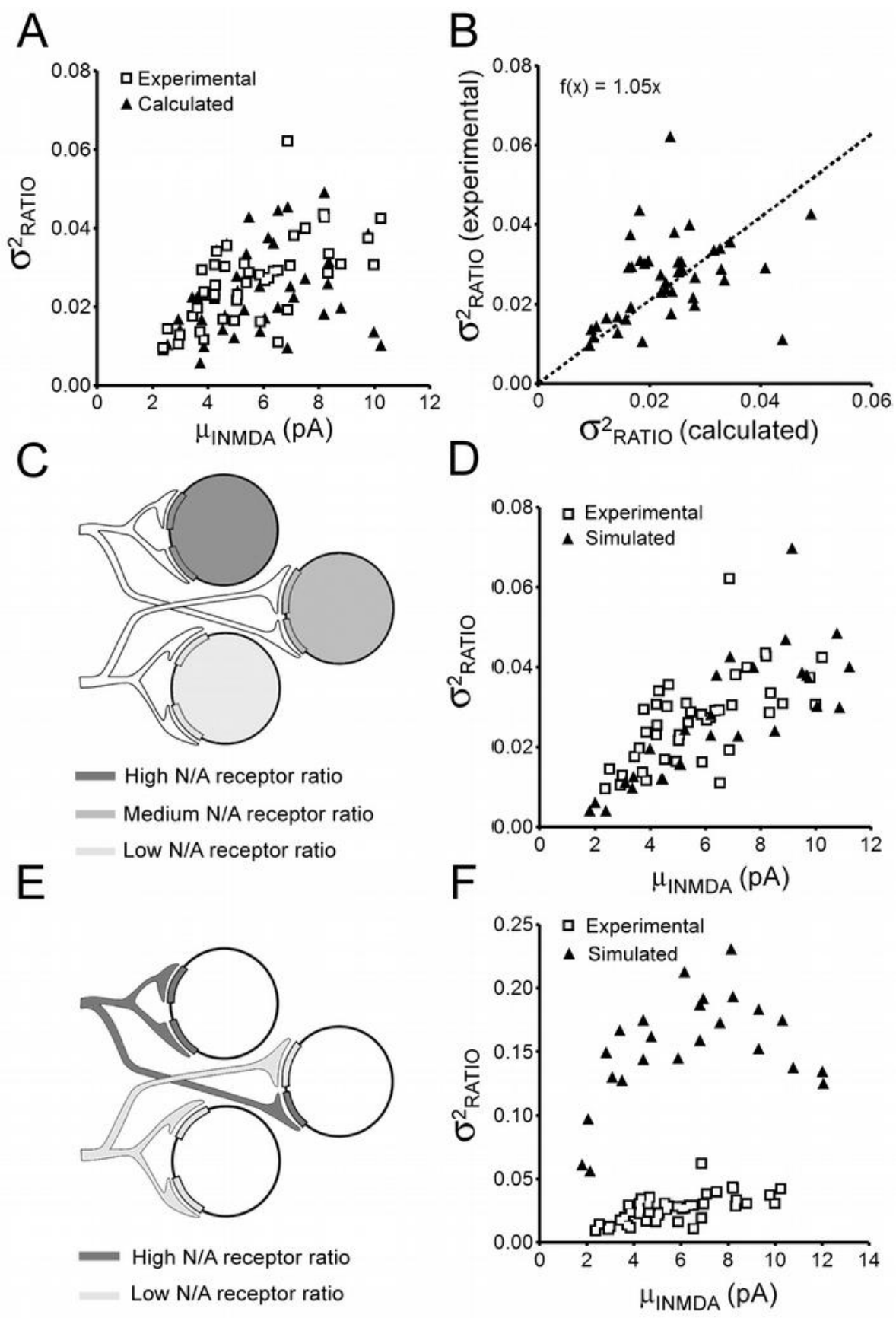

522 Figure 4.A. Variance of $\mathrm{I}_{\mathrm{NMDA}} / \mathrm{I}_{\mathrm{AMPA}}$ ratio across mEPSCs of recorded neurons as a function of mean

$523 \mathrm{I}_{\mathrm{NMDA}}$. Note the overlap between experimental data (empty squares) and variances values recalculated

524 for the same neurons using equation 4 (solid triangles). B. Regression of experimental ratio variance

525 values on values recalculated using equation 4 . The slope of the regression line (origin forced to 0,0 ) is 
526 close to one indicating that $\mathrm{I}_{\mathrm{NMDA}}$ contribution to ratio variability mas mostly due to NMDA receptor

527 channel noise. C. Schematic representation of scenario 1 assuming identical NMDA to AMPA receptor

528 ratio across synapses onto the same target cell. Simulation was performed in 27 series (each

529 representing a different neuron) of 50 runs (each representing a different quantal event). The number of

530 AMPA receptor was set to 100 throughout runs and series. The number of NMDA receptors was

531 identical across runs within a series but increased from 10 to 100 across series. D. Comparison between

532 ratio variances obtained from recorded neurons (empty squares) and neurons simulated using scenario 1

533 (solid triangles). Note the strong overlap between the two sets of data. E. Schematic representation of

534 scenario 2 assuming different NMDA to AMPA receptor ratio across synapses onto the same target cell.

535 Simulation was performed in 27 series (each representing a different neuron) of 50 runs (each

536 representing a different quantal event). The number of AMPA receptor was set to 100 throughout runs

537 and series. The number of NMDA receptor was either 5 or 120 depending on the run. The proportion of

538 runs with 120 NMDA receptors increased (from 5:50 to 45:50) across series. F. Comparison between

539 ratio variances obtained from recorded neurons (empty squares) and neurons simulated using scenario 2

540 (solid triangles). Note that ratio variances obtained by simulation using different NMDA to AMPA

541 receptor ratio across synapses onto the same target cell were much higher than those obtained

542 experimentally. 

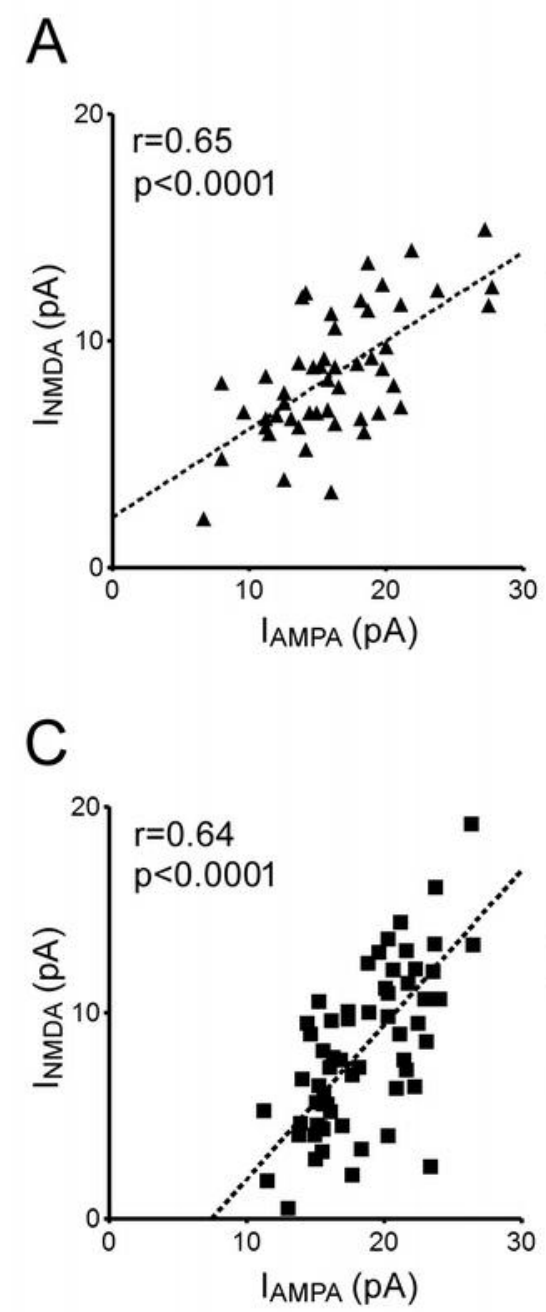
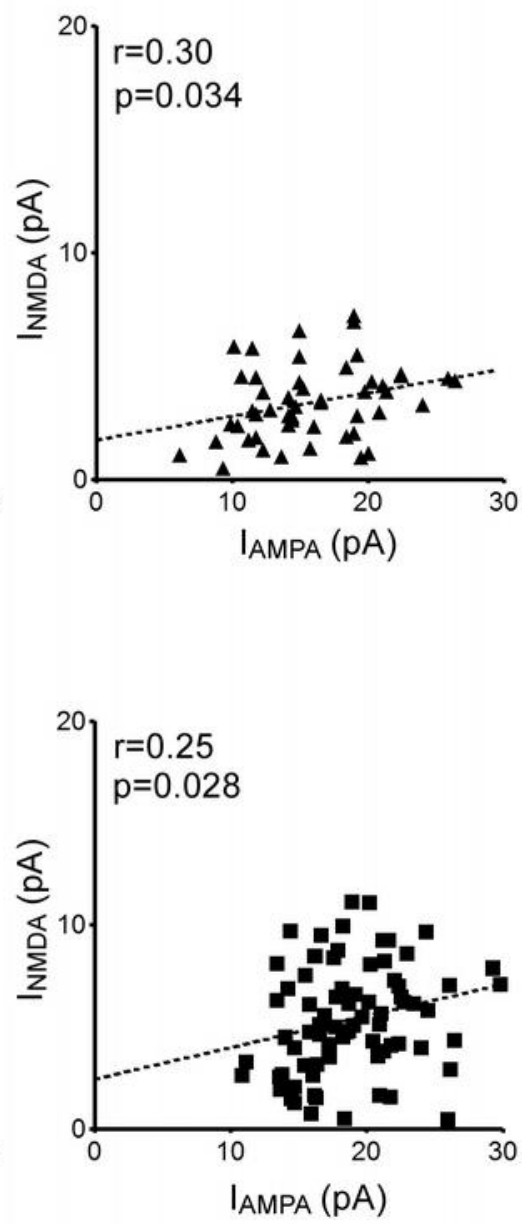

B

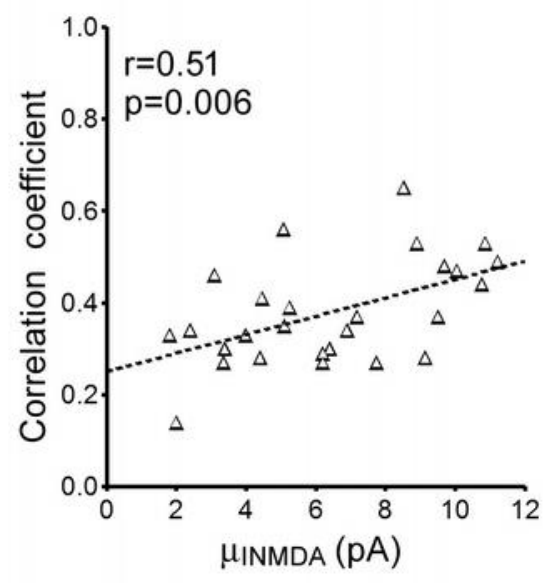

$\mathrm{D}$

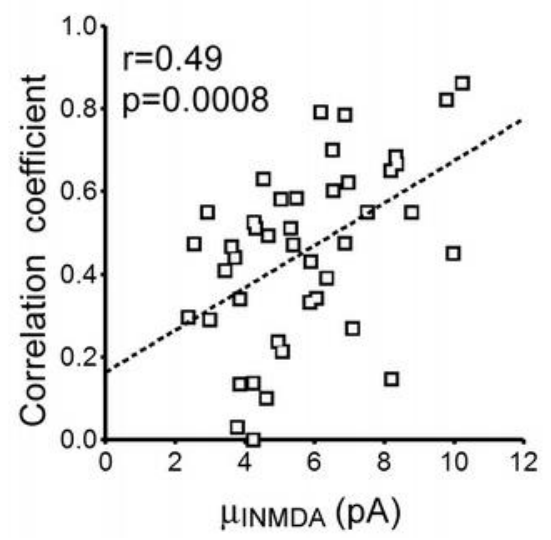

543 Fig. 5A. Example of correlation between NMDA current amplitudes $\left(\mathrm{I}_{\mathrm{NMDA}}\right)$ and AMPA current

544 amplitudes $\left(\mathrm{I}_{\mathrm{AMPA}}\right)$ across quantal events from two neurons simulated using scenario1. Note the

545 difference in correlation strength between the two neurons. B. Relationship between $\mu_{\text {INMDA }}$ and $\mathrm{I}_{\mathrm{NMDA}^{-}}$

$546 \mathrm{I}_{\mathrm{AMPA}}$ correlation strength across neurons simulated using scenario 1. C. Correlation between NMDA

547 current amplitudes $\left(\mathrm{I}_{\mathrm{NMDA}}\right)$ and AMPA current amplitudes $\left(\mathrm{I}_{\mathrm{AMPA}}\right)$ across mEPSCs recorded from two

548 NTS projection neurons. D. Relationship between $\mu_{\mathrm{INMDA}}$ and $\mathrm{I}_{\mathrm{NMDA}}-\mathrm{I}_{\mathrm{AMPA}}$ correlation strength across 549 recorded neurons. 